\title{
SMOOTHING IN NEURAL NETWORK FOR UNIVARIAT TIME SERIES DATA FORECASTING
}

\author{
Nurfia Oktaviani Syamsiah ${ }^{1}$, Indah Purwandani ${ }^{2}$ \\ Sistem Informasi Akuntansi Akuntansi Kampus Kota Pontianak, Fakultas Teknik dan Informatika ${ }^{1}$ \\ Sistem Informasi Akuntansi Akuntansi Kampus Kota Bogor, Fakultas Teknik dan Informatika ${ }^{2}$ \\ Universitas Bina Sarana Informatika ${ }^{1,2}$ \\ nurfia.nos@bsi.ac.id ${ }^{1}$, indah@bsi.ac.id ${ }^{2}$
}

\begin{abstract}
Abstrak
Data runtun waktu menjadi suatu bahan penelitian yang menarik bagi banyak pihak. Tidak sedikit model yang sudah dihasilkan, namun belum didapatkan akurasi yang sangat optimal. Neural network adalah salah satu yang banyak digunakan karena kemampuannya untuk memahami hubungan non linier antar data. Penelitian ini akan menggabungkan neural network dengan exponential smoothing untuk menghasilkan akurasi yang lebih tinggi. Exponential smoothing sebagai salah satu metode linier terbaik digunakan untuk transformasi data set dan untuk selanjutnya data set baru tersebut akan digunakan dalam training dan testing model Neural Network. Model yang dihasilkan akan dievaluasi menggunakan ukuran kesalahan standar Root Mean Square Error (RMSE). Setiap model dibandingkan nilai RMSE nya dan kemudian dilakukan T-Test. Model ES-NN yang diusulkan ternyata terbukti hasil prediksinya lebih baik daripada penggunaan satu metode saja, walaupun hasilnya tidak terlalu signifikan.
\end{abstract}

Kata kunci: Univariat, Runtun Waktu, Smoothing, Jaringan Syaraf

\begin{abstract}
Time series data is interesting research material for many people. Not a few models have been produced, but very optimal accuracy has not been obtained. Neural network is one that is widely used because of its ability to understand non-linear relationships between data. This study will combine a neural network with exponential smoothing to produce higher accuracy. Exponential smoothing is one of the best linear methods is used for data set transformation and thereafter the new data set will be used in training and testing the Neural Network model. The resulting model will be evaluated using the standard error measure Root Mean Square Error (RMSE). Each model was compared with its RMSE value and then performed a T-Test. The proposed ES-NN model proved to have better predictive results than using only one method.
\end{abstract}

Keywords: Univariate, Time Series, Smoothing, Neural Network

\section{INTRODUCTION}

Forecasting using time series data is one of the options in automation and optimization of business processes and plays a key role in automating and optimizing operational processes (Faloutsos, Flunkert, Gasthaus, Januschowski, \& Wang, 2019). Also, accurate forecasting results will be very helpful in the decision-making process concerning various matters such as the number of foreign tourists (Mudiyanselage \& Banda, 2018), the number of requests in the hospital emergency department (Aboagye-Sarfo et al., 2015), number of daily requests for hotel rooms (Phumchusri \& Ungtrakul, 2020), total sales revenue (Penpece \& Elma, 2014), number of excavator requests (Zhao, Wang, Zhang, \& Han, 2019), to the forecasted amount of rice production (Putra \& Ulfa Walmi, 2020), and many other things. Anything that has time series data can be predicted or predicted what the value or amount is for the next period.

The time-series data used could be univariate (Nazaripouya et al., 2016), (Essien, 2019), (Fischer, Pohl, \& Ratz, 2020), (Essien, 2019), multivariate (Hu et al., 2018), (Hassani, Rua, Silva, \& Thomakos, 2019), (Koutlis, Papadopoulos, Schinas, \& Kompatsiaris, 2020), (Hu et al., 2018) or a combination and comparison of the two (Sethi \& Mittal, 2020), (Iwok \& Okpe, 2016), (Zhang, Zhong, Geng, \& Jiang, 2017), (Goswami, Ganguly, \& Kumar Sil, 2019). Multivariate means that there is more than one input parameter used. Meanwhile, univariate uses one variable, namely the value at present or the previous time. Univariate does not 
need additional tools, only a dataset, so it becomes relatively more efficient. Another thing, in highspeed dynamic control, which requires short-term forecasting, the univariate method becomes more effective because it does not depend on prolonged data acquisition (Majidpour, Nazaripouya, Chu, Pota, \& Gadh, 2018).

Many algorithms have been used by researchers in forecasting univariate time series data, including Neural Networks (Penpece \& Elma, 2014) (Syamsiah, 2020), SVM (He, 2019), Fuzzy Rule Base (Maciel \& Ballini, 2017), Genetics Algorithms (Al-Douri, Hamodi, \& Lundberg, 2018), Bagging (Athanasopoulos, Song, \& Sun, 2017) as well as Exponential Smoothing (Ferbar Tratar, Mojškerc, \& Toman, 2016).

Of the many studies, Neural Network (NN) is one of the most popular nonlinear techniques that are efficient for time series forecasting. Some of the reasons are, among others, because NN does not assume linearity but has an adaptive nature, namely having the ability to adjust to non-linear functions. So that the right combination of these algorithms will provide better time series data forecasting results (Aishwarya \& Babu, 2017). NN also can extract important features and study complex information patterns in high dimensional space (Arevalo, 2016).

Unfortunately, although the Neural Network is a superior nonlinear model, it still has limitations in the accuracy of forecasting results when there is a magnitude at the highest frequency and there is a lot of noise in the data. Besides, learning patterns that have nonlinear characteristics, complex dimensions, and noise that appear, cause the cessation of training at the minimum locale resulting in poor performance (Muhamad \& Din, 2016).

However, in line with the development of research, new challenges always arise in forecasting time series data. Although many models have been produced, it turns out that there is no one unique model that can predict accurately, this is due to the variety of applications. Also, there is an assumption that the use of one method alone cannot identify all the characteristics of the timeseries data (Gunaryati, Kasyfi, \& Andryana, 2019). Instead of applying one algorithm, the hybrid model gives more satisfying results (Aishwarya \& Babu, 2017). It is at this point that the challenge grows, namely implementing more than one simple algorithm but providing efficiency and of course more accurate results.

Integration of algorithms that have been performed for forecasting among others ARIMALS-SVM in stock value forecasting (Xiao, Xia, \&
Jiang, 2020), SVM-GA in PM 2.5 forecasting and meteorological data (Chuentawat \& Kan-Ngan, 2019), NN with GA (Aishwarya \& Babu, 2017), NN with ARIMA in forecasting network traffic (Wang, Wang, Zhang, \& Zhang, 2015).

This research will combine two methods, namely ES and NN. Several other studies that are also of the same type include forecasting electrical loads where the combination of the two can produce better accuracy (Sulandari, Subanar, Suhartono, \& Utami, 2016), (Mohammed, Bahadoorsingh, Ramsamooj, \& Sharma, 2017), the application of NN to ES can reduce the error forecasting results by up to 6 percent (Parsi, 2016), TES-F provides better accuracy than forecasting with TES alone (Fajriyah et al., 2019), The combination of ES NN in predicting the number of broadband users in Indonesia can significantly improve accuracy than using only one method (Gunaryati et al., 2019), forecasting model produced by combining the ES-NN provides high accuracy (Smyl, 2020), and it turns out that the smoothing that has been done on the data can improve the performance of $\mathrm{NN}$ training (Muhamad \& Din, 2016).

Excellent ES application for linear data (de Faria, Albuquerque, Gonzalez, Cavalcante, \& Albuquerque, 2009) combined with NN which has adaptive properties and has significant results for non-linear data patterns (Sulandari et al., 2016), expected to improve forecasting performance and accuracy. Overfitting on NN that often occurs will be overcome by using more training data (Muladi, Siregar, \& Wibawa, 2018). Then the noise that often appears in the data set will be reduced by smoothing the data (Kulakov, 2004), and the smoothing selected is ES. Smoothing with ES will be done at the pre-processing stage that is before the data is processed in training and testing at NN (Chan, Dillon, Singh, \& Chang, 2011) (Suryani \& Wahono, 2015).

As for the difference from previous studies, in this study, the parameter selection in NN was carried out through optimization using the existing operator on Rapid Miner. The data set used is different, where this study uses a data set of daily sales at a supermarket for three years.

\section{RESEARCH METHODS}

Exponential Smoothing is usually used for short-term forecasting with stationary data patterns. The simple mathematical formula is:

$F_{t+1}=\alpha X_{t}+(1-\alpha) F_{t}$ 


\section{t: period}

$F_{t+1}:$ forecasting period $t+1$

$F_{t}$ : forecasting period $\mathrm{t}$

$X_{t}$ : value at time $\mathrm{t}$

$\alpha$ : smoothing parameters, between 0 and 1

Data without trend when using simple exponential smoothing will produce a minimum error if the $\alpha$ value is small, in the range $0.0-0.3$. This applies to the small $(n=12)$ and large $(n=60)$ series. If the initial forecast value is significant, the $\alpha$ value will very often be zero. The small nonzero value of $\alpha$ indicates a local trend. A larger nonzero $\alpha$ value indicates a continuous trend which may be better explained by double exponential smoothing. Large smoothing constant values are of course possible and should not be rejected without a detailed examination of the underlying set or the quality of the initial forecasts used. When there is a linear trend in the data, the performance of double exponential smoothing depends on the initial estimates of the level and trend components. If the result is significant, $\alpha$ and $\beta$ will be very small. This applies to both small and large series. Larger values may indicate poor initial forecasts of levels and trends. The impact of poor initial forecasts was felt less in a longer series than in smaller series. The values of $\alpha$ and $\beta$ decrease with the length of the circuit. When there are nonlinear trends in the data, the results are mixed and are not easy to generalize. The best values of $\alpha$ and $\beta$ depend on the particular nonlinearity involved. The best approach is to graph the time series and select the appropriate initial values before finding the optimal values for $\alpha$ and $\beta$ (Ravinder, 2013).

Neural Networks usually consist of three types of layers. The first is the input layer which communicates with the outside environment which displays patterns. Each input neuron must represent several independent variables that influence the resulting output. The second output layer displays the pattern to the outside environment, the pattern presented by the output layer can be directly traced back to the input layer. The number of output neurons must be directly related to the type of process to be carried out. The third is a hidden layer which is a collection of neurons with activated activation functions and provides an intermediate layer between the input layer and the output layer.

Many studies have been conducted to evaluate the number of neurons in hidden layers but still, none is accurate. The determination of the number of hidden layers and hidden nodes in this study is following the rules, namely, the number of hidden nodes is $60 \%-90 \%$ of the number of input layers, the number of hidden nodes must not exceed 2 times the number of input nodes and the number of hidden layers must be between the number of input layers and the number. output layer (Mohammed et al., 2017).

The rule of thumb noted above for determining the number of hidden nodes is not always correct because, in addition to the input and output layers, the complexity of the activation function, training algorithms, neural network architecture, and training data can influence the determination of the number of hidden layers. Several hidden layers can also be combined in the $\mathrm{NN}$ architecture, this can increase the functionality used, without having a severe impact on the training period. However, by increasing the number of hidden layers there is another effect, namely the possibility of $\mathrm{NN}$ falling to a local minimum. In practice, knowledge of the tasks to be performed and the criteria that the neural network must meet are major factors in determining the number of hidden nodes and hidden layers.

By increasing the number of hidden layers to three layers, accuracy can be achieved to a certain extent, but the complexity of the neural network and training times are increased many times. If accuracy is the main criterion for designing a neural network, then the hidden layers can be improved. Besides, an unnecessary increase in neurons or lining will cause overfitting problems. So it is imperative that before designing neural networks the training database sample should be analyzed so that the approximate number of neurons and hidden layers can be correctly guessed.

This study utilizes Exponential Smoothing for forecasting actual data while the Neural Network is used for forecasting the errors obtained because it can model a nonlinear time series without a trend.

The combination of these two methods is expected to produce higher accuracy than when using each method independently. The process carried out is to use the results of ES as input for $\mathrm{NN}$, as shown in Figure 1.

As seen in Figure 1, the process begins with the preparation of the data set, namely the time series data mentioned in the previous section. Furthermore, the pre-processing is carried out by utilizing the replace missing value feature which is the data cleansing operator in Rapid Miner, this operator handles the possible existence of a null value in the data, besides that it is also used to find the missing value in the attribute then adjusted as needed. 


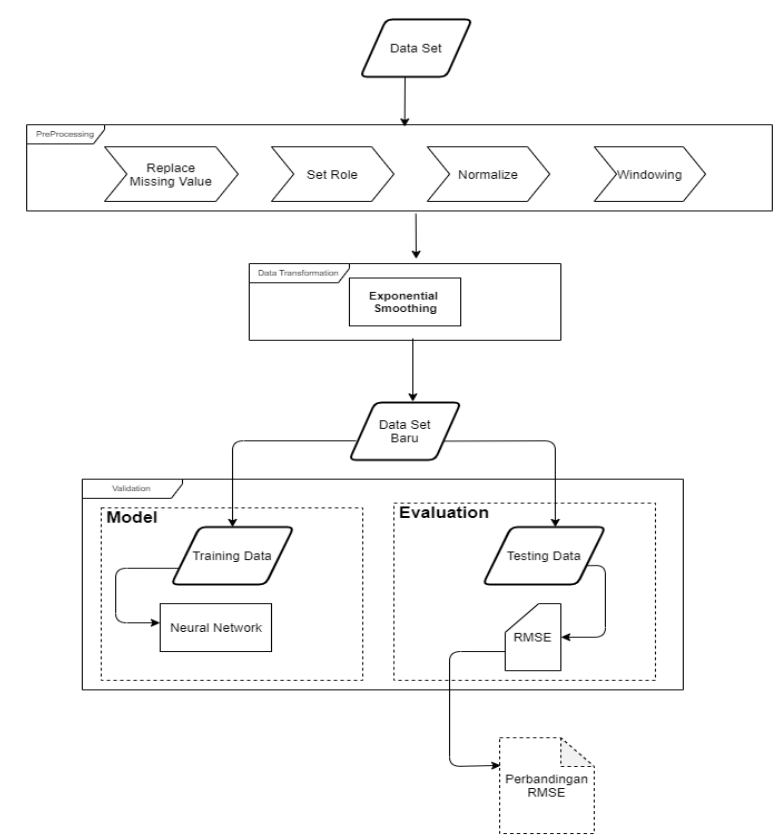

Figure 1. Research Algorithm

The next step is to determine the role of each attribute, in RapidMiner, uses the set role operator. This stage is vital because classification operators tend to work better when the number of attributes with role labels in the dataset is minimal. Attributes other than that will automatically have a regular role. For unique attributes that provide identification, they are used as id.

After the set role stage, the next step is data normalization by utilizing the normalize operator in Rapid Miner. This normalization is for all attributes and their values are in the range of 0 to 1 . This stage is also important because the differences in the scale of the attributes in the dataset will affect the distance calculation. The next process is windowing, this process is changing the time series data into an example set containing several attributes that correspond to successive values. Apart from that, windowing is also used to visualize data. Next is data transformation by applying Exponential Smoothing. And the results will be used for training and testing using the Neural network. Training and testing to apply KFold Cross-Validation for data sharing. 10 Folds are used because this value has been widely used in previous research and produces the most accurate validation (Peng et al., 2017).

Mean Absolute Error (MAE) and Root Mean Square Error (RMSE) was used to measure the performance produced by each model in this study. Then proceed with comparisons using the T-Test to validate the significant difference between the actual value and the predicted value (Mapuwei, Bodhlyera, \& Mwambi, 2020).

\section{RESEARCH RESULTS AND DISCUSSION}

The best Neural network model can only be generated by trial-error, which is changing the values of each parameter randomly until the best model is produced with the highest accuracy. (Astray et al., 2019). However, the use of Rapid Miner can simplify this trial-error process due to the availability of the Performa operator. So that the value to be carried out by trial-error is enough to input the minimum and maximum limits, then the process will be carried out by the operator.

Based on a single method study comparing two activation functions (Syamsiah \& Purwandani, 2019), The lowest RMSE is generated by the binary sigmoid function, so even this forecasting process applies this function to data normalization. Furthermore, the data that has gone through the stages of set roles, normalization, and windowing are first performed smoothing using ES, then training and testing will be carried out using the selected activation function.

The result is that there is a difference in the level of accuracy between the two methods as seen in Figure 2 and Figure 3, namely the application of NN produces RMSE 0.117 and by combining the two results in RMSE 0.111 . Where the difference is only $0.6 \%$. The results of the TTest also showed that the differences were not significant between the two methods produced. Where is shown in Figure 4.

Based on this, the application of ES and NN for forecasting time series univariate data using daily sales data for three years has not been able to produce high accuracy. This could be due to the unsuitability of the smoothing type selected with the type of data set being used. Therefore, it is necessary to optimize smoothing parameters or use a different type of smoothing.

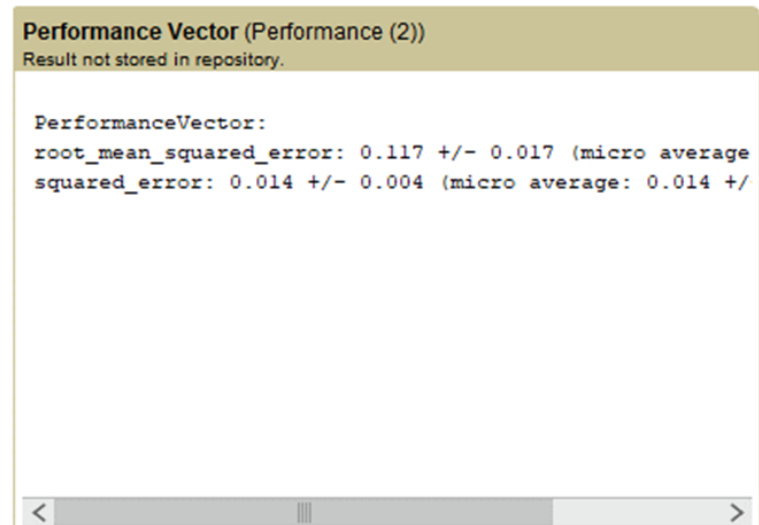

Figure 2. RMSE results from NN 


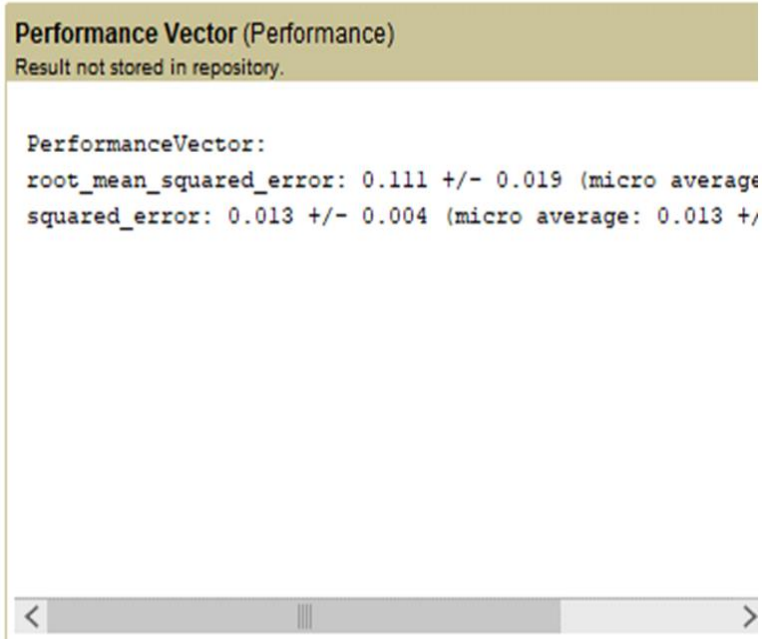

Figure 3. RMSE results from the ES-NN

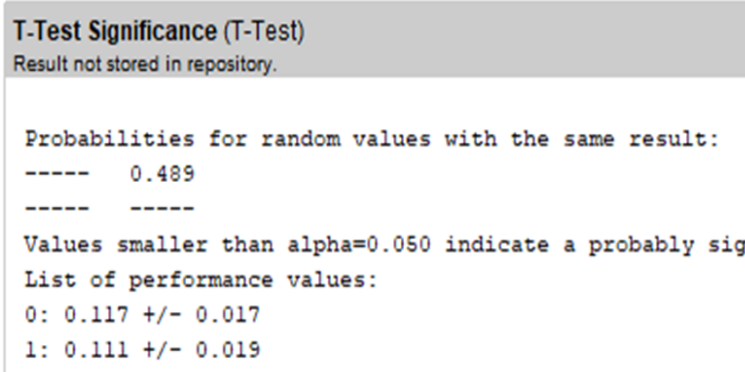

Figure 4. The results of the T-Test for the two prediction models

\section{CONCLUSIONS AND SUGGESTION}

\section{Conclusions}

Forecasting time series data will produce higher accuracy when more than one method is used. As in this study, it has been proven that the use of exponential smoothing on Neural Network input data can increase the accuracy up to $0.6 \%$. Henceforth, further research is needed by applying the comparison between the use of univariate and multivariate data. Or by using several other algorithms to get even more accurate results.

\section{Suggestion}

Future studies can apply other algorithms both for data normalization, overcoming missing values, or for the forecasting process. So that a comparison can be made with the results of current research. Also, more diverse research data can be used to obtain a more diverse comparison.

\section{REFERENCE}

Aboagye-Sarfo, P., Mai, Q., Sanfilippo, F. M., Preen, D. B., Stewart, L. M., \& Fatovich, D. M. (2015). A comparison of multivariate and univariate time series approaches to modelling and forecasting emergency department demand in Western Australia. Journal of Biomedical Informatics, 57, 62-73. https://doi.org/10.1016/j.jbi.2015.06.022

Aishwarya, D. C., \& Babu, C. N. (2017). Prediction of time series data using GA-BPNN based hybrid ANN model. Proceedings - 7th IEEE International Advanced Computing Conference, IACC 2017, 848-853. https://doi.org/10.1109/IACC.2017.0174

Al-Douri, Y. K., Hamodi, H., \& Lundberg, J. (2018). Time series forecasting using a two-level multi-objective genetic algorithm: A case study of maintenance cost data for tunnel fans. Algorithms, 11(8), 4-9. https://doi.org/10.3390/a11080123

Arevalo, A. (2016). Short-Term Forecasting of Financial Time Series with Deep Neural Networks, 42. Retrieved from http://www.bdigital.unal.edu.co/54538/

Astray, G., Mejuto, J. C., Martínez-Martínez, V., Nevares, I., Alamo-Sanza, M., \& SimalGandara, J. (2019). Prediction models to control aging time in red wine. Molecules, 24(5).

https://doi.org/10.3390/molecules2405082 6

Athanasopoulos, G., Song, H., \& Sun, J. A. (2017). Bagging in Tourism Demand Modeling and Forecasting. Journal of Travel Research, 1-17. https://doi.org/10.1177/004728751668287 1

Chan, K. Y., Dillon, T. S., Singh, J., \& Chang, E. (2011). Traffic flow forecasting neural networks based on exponential smoothing method. Proceedings of the 2011 6th IEEE Conference on Industrial Electronics and Applications, ICIEA 2011, 376-381. https://doi.org/10.1109/ICIEA.2011.597561 2

Chuentawat, R., \& Kan-Ngan, Y. (2019). The comparison of PM2.5 forecasting methods in the form of multivariate and univariate time series based on support vector machine and genetic algorithm. ECTI-CON 2018 - 15th International Conference on Electrical Engineering/Electronics, Computer, Telecommunications and Information 
Technology,

572-575.

https://doi.org/10.1109/ECTICon.2018.8619 867

de Faria, E. L., Albuquerque, M. P., Gonzalez, J. L., Cavalcante, J. T. P., \& Albuquerque, M. P. (2009). Predicting the Brazilian stock market through neural networks and adaptive exponential smoothing methods. Expert Systems with Applications, 36(10), 1250612509.

https://doi.org/10.1016/j.eswa.2009.04.032

Essien, A. (2019). A Deep Learning Framework for Univariate Time Series Prediction Using Convolutional LSTM Stacked Autoencoders. 2019 IEEE International Symposium on Innovations in Intelligent SysTems and Applications (INISTA), 1-6.

Fajriyah, R., Asfah, I., Teknik, F., Kartini, U. T., Teknik, F., Surabaya, U. N., ... Error, P. (2019). Peramalan Radiasi Global Matahari Jangka Pendek Menggunakan ModelTriple Exponential Smoothing-Feed Forward Neural Network, 677-684.

Faloutsos, C., Flunkert, V., Gasthaus, J., Januschowski, T., \& Wang, Y. (2019). Forecasting big time series: Theory and practice. Proceedings of the ACM SIGKDD International Conference on Knowledge Discovery and Data Mining, 2309-2310. https://doi.org/10.1145/3292500.3332289

Ferbar Tratar, L., Mojškerc, B., \& Toman, A. (2016). Demand forecasting with four-parameter exponential smoothing. International Journal of Production Economics, 181, 162-173. https://doi.org/10.1016/j.ijpe.2016.08.004

Fischer, J. A., Pohl, P., \& Ratz, D. (2020). A machine learning approach to univariate time series forecasting of quarterly earnings. Review of Quantitative Finance and Accounting, (0123456789).

https://doi.org/10.1007/s11156-02000871-3

Goswami, K., Ganguly, A., \& Kumar Sil, A. (2019). Comparing univariate and multivariate methods for short term load forecasting. 2018 International Conference on Computing, Power and Communication Technologies, GUCON 2018, 972-976. https://doi.org/10.1109/GUCON.2018.86750 59

Gunaryati, A., Kasyfi, F., \& Andryana, S. (2019). HYBRID EXPONENTIAL SMOOTHING NEURAL NETWORK UNTUK HYBRID EXPONENTIAL SMOOTHING NEURAL NETWORK UNTUK PERAMALAN DATA PENGGUNA PITA, (August).
Hassani, H., Rua, A., Silva, E. S., \& Thomakos, D. (2019). Monthly forecasting of GDP with mixed-frequency multivariate singular spectrum analysis. International Journal of Forecasting, 35(4), 1263-1272. https://doi.org/10.1016/j.ijforecast.2019.03. 021

He, J. (2019). Ultra-short-term wind speed forecasting based on support vector machine with combined kernel function and similar data, 1-7.

Hu, Y., Xia, X., Fang, J., Ding, Y., Jiang, W., \& Zhang, N. (2018). A multivariate regression load forecasting algorithm based on variable accuracy feedback. Energy Procedia, 152, 1152-1157.

https://doi.org/10.1016/j.egypro.2018.09.14 7

Iwok, I. A., \& Okpe, A. S. (2016). A Comparative Study between Univariate and Multivariate Linear Stationary Time Series Models. American Journal of Mathematics and Statistics, 6(5), 203-212. https://doi.org/10.5923/j.ajms.20160605.02

Koutlis, C., Papadopoulos, S., Schinas, M., \& Kompatsiaris, I. (2020). LAVARNET: Neural network modeling of causal variable relationships for multivariate time series forecasting. Applied Soft Computing Journal, 96,

106685. https://doi.org/10.1016/j.asoc.2020.106685

Kulakov, A. (2004). SINGLE EXPONENTIAL SMOOTHING METHOD AND NEURAL NETWORK IN ONE METHOD, 1-3.

Maciel, L., \& Ballini, R. (2017). Interval fuzzy rulebased modeling approach for financial time series forecasting. IEEE International Conference on Fuzzy Systems. https://doi.org/10.1109/FUZZIEEE.2017.8015654

Majidpour, M., Nazaripouya, H., Chu, P., Pota, H., \& Gadh, R. (2018). Fast Univariate Time Series Prediction of Solar Power for Real-Time Control of Energy Storage System. Forecasting, 1(1), 107-120. https://doi.org/10.3390/forecast1010008

Mapuwei, T. W., Bodhlyera, O., \& Mwambi, H. (2020). Univariate Time Series Analysis of Short-Term Forecasting Horizons Using Artificial Neural Networks: The Case of Public Ambulance Emergency Preparedness. Journal of Applied Mathematics, 2020. https://doi.org/10.1155/2020/2408698

Mohammed, J., Bahadoorsingh, S., Ramsamooj, N., \& Sharma, C. (2017). Performance of exponential smoothing, a neural network and 
a hybrid algorithm to the short-term load forecasting of batch and continuous loads. 2017 IEEE Manchester PowerTech, Powertech 2017.

https://doi.org/10.1109/PTC.2017.7980816

Mudiyanselage, K., \& Banda, U. (2018). Forecasting Ability of Univariate Time Series Approach in Foreign Guest Nights in the Southern Coast of Sri Lanka, 5(August), 17-25.

Muhamad, N. S., \& Din, A. M. (2016). Neural Network Forecasting Model using Smoothed Data. In The 4th International Conference on Quantitative Sciences and Its Applications (ICOQSIA 2016) (Vol. 4). https://doi.org/10.1063/1.4966079

Muladi, Siregar, S. A., \& Wibawa, A. P. (2018). Double Exponential-Smoothing Neural Network for Foreign Exchange Rate Forecasting. Proceedings - 2nd East Indonesia Conference on Computer and Information Technology: Internet of Things for Industry, EIConCIT 2018, 118-122. https://doi.org/10.1109/EIConCIT.2018.887 8591

Nazaripouya, H., Wang, B., Wang, Y., Chu, P., Pota, H. R., \& Gadh, R. (2016). Univariate time series prediction of solar power using a hybrid wavelet-ARMA-NARX prediction method. Proceedings of the IEEE Power Engineering Society Transmission and Distribution Conference, 2016-July, 1-5. https://doi.org/10.1109/TDC.2016.7519959

Parsi, M. (2016). Hybrid Irradiation Forecasting Method Using Neural Network To Reduce Exponential Smoothing Error. IOSR Journal of Mechanical and Civil Engineering (IOSRJMCE), 13(5), 46-51. https://doi.org/10.9790/1684-1305034651

Peng, J., Kim, M., Jo, M., Min, D., Kim, K., Lee, B., \& Kim, B. (2017). Accuracy Evaluation of the Crop-Weather Yield Predictive Models of Italian Ryegrass and Forage Rye Using CrossValidation, 2017(10), 327-334.

Penpece, D., \& Elma, O. E. (2014). Predicting Sales Revenue by Using Artificial Neural Network in Grocery Retailing Industry: A Case Study in Turkey. International Journal of Trade, Economics and Finance, 5(5), 435-440. https://doi.org/10.7763/ijtef.2014.v5.411

Phumchusri, N., \& Ungtrakul, P. (2020). Hotel daily demand forecasting for high-frequency and complex seasonality data: a case study in Thailand. Journal of Revenue and Pricing Management, 19(1), 8-25. https://doi.org/10.1057/s41272-01900221-6
Putra, H., \& Ulfa Walmi, N. (2020). Penerapan Prediksi Produksi Padi Menggunakan Artificial Neural Network Algoritma Backpropagation. Jurnal Nasional Teknologi Dan Sistem Informasi, 6(2), 100-107. https://doi.org/10.25077/teknosi.v6i2.2020. 100-107

Ravinder, H. V. (2013). Forecasting With Exponential Smoothing What's The Right Smoothing Constant? Review of Business Information Systems (RBIS), 17(3), 117-126. https://doi.org/10.19030/rbis.v17i3.8001

Sethi, J. K., \& Mittal, M. (2020). Analysis of air quality using univariate and multivariate time series models. Proceedings of the Confluence 2020 - 10th International Conference on Cloud Computing, Data Science and Engineering, 823-827. https://doi.org/10.1109/Confluence47617.2 020.9058303

Smyl, S. (2020). A hybrid method of exponential smoothing and recurrent neural networks for time series forecasting. International Journal of Forecasting, 36(1), 75-85. https://doi.org/10.1016/j.ijforecast.2019.03. 017

Sulandari, W., Subanar, Suhartono, \& Utami, H. (2016). Forecasting electricity load demand using hybrid exponential smoothing-artificial neural network model. International Journal of Advances in Intelligent Informatics, 2(3), 131-139.

https://doi.org/10.26555/ijain.v2i3.69

Suryani, I., \& Wahono, R. S. (2015). Penerapan Exponential Smoothing untuk Transformasi Data dalam Meningkatkan Akurasi Neural Network pada Prediksi Harga Emas. Journal of Intelligent Systems, 1(2), 67-75.

Syamsiah, N. O. (2020). PERAMALAN HARGA TELUR AYAM RAS DI JAKARTA TIMUR. Journal of Computer Engineering, System and Science, 5(1), 65-69.

Syamsiah, N. O., \& Purwandani, I. (2019). Penerapan Neural Network Untuk Peramalan Data Time Series Univariate Jumlah Wisatawan Mancanegara. Jurnal Mantik Penusa, 3(3), 100-106. Retrieved from http://ejurnal.pelitanusantara.ac.id/index.php/manti $\mathrm{k} /$ article/view/675

Wang, C., Wang, G., Zhang, X., \& Zhang, S. (2015). Direct Forecast Method Based on ANN in Network Traffic Prediction. In W. E. Wong (Ed.), International Conference on Computer Engineering and Networks (pp. 477-484). Switzerland: Springer International 
Publishing. https://doi.org/10.1007/978-3319-11104-9

Xiao, C., Xia, W., \& Jiang, J. (2020). Stock price forecast based on combined model of ARIMA-LS-SVM. Neural Computing and Applications, https://doi.org/10.1007/s00521-01904698-5

Zhang, Y., Zhong, M., Geng, N., \& Jiang, Y. (2017). Forecasting electric vehicle sales with univariate and multivariate time series models: The case of China. PLoS ONE, 12(5),
$1-15$.

https://doi.org/10.1371/journal.pone.01767 29

Zhao, J., Wang, Z., Zhang, Z., \& Han, Y. (2019). A combined model based on GM and SARIMA: An example of excavator demand forecasting. 2019 IEEE 4th International Conference on Cloud Computing and Big Data Analytics, ICCCBDA 2019, 232-236. https://doi.org/10.1109/ICCCBDA.2019.872 5752 